\title{
Simultaneous detection of four viruses affecting apple and pear by molecular hybridization using a polyprobe
}

\author{
Detecção simultânea de quatro vírus que infectam macieiras e pereiras por meio \\ de hibridização molecular com uma polissonda
}

\author{
Thor Vinícius Martins Fajardo ${ }^{\mathrm{I}^{*}}$ Osmar Nickel $^{\mathrm{I}}$
}

\section{ABSTRACT}

The viruses Apple stem grooving virus (ASGV), Apple chlorotic leaf spot virus (ACLSV), Apple stem pitting virus (ASPV) and Apple mosaic virus (ApMV) are common in apples and pears and main targets of detection in propagation materials. This study aimed at demonstrating the usefulness of the hybridization method with a non-radioactive probe for simultaneous detection of these four viruses. The sensitivity of this method was sufficiently high enabling the detection of ASGV, ACLSV, ASPV and ApMV in total $R N A$ extracted from infected samples. The probe specificity was confirmed by reaction with homologous viral cDNA, individually cloned for each virus.
\end{abstract}

- NOTE
Key words: diagnosis, Malus, Pyrus, polyprobe, ASGV, ACLSV, ASPV, ApMV.

\section{RESUMO}

Os vírus Apple stem grooving virus (ASGV), Apple chlorotic leaf spot virus (ACLSV), Apple stem pitting virus (ASPV) e Apple mosaic virus (ApMV) são comuns em macieiras e pereiras e alvos prioritários da detecção em materiais propagativos. Este trabalho objetivou demonstrar a viabilidade do método de hibridização com uma sonda não-radioativa para a deteç̧ão simultânea desses quatro vírus. A sensibilidade deste teste foi suficientemente alta para permitir a detecção do ASGV, ACLSV, ASPV e ApMV em RNA total extraído de amostras infectadas. A especificidade da sonda foi confirmada pela reação com cDNA viral homólogo, individualmente clonado, para cada vírus.

Palavras-chave: diagnose, Malus, Pyrus, polissonda, ASGV, $A C L S V, A S P V, A p M V$

Virus infections are a common occurrence in apples and pears grown in Brazil (NICKEL et al., 2001). Among apples (Malus domestica) and pears (Pyrus spp.) viruses as Apple stem grooving virus (ASGV, Capillovirus), Apple chlorotic leaf spot virus (ACLSV, Trichovirus) and Apple stem pitting virus (ASPV, Foveavirus), Betaflexiviridae family, and Apple mosaic virus (ApMV, Ilarvirus, Bromoviridae) stand out for their frequency and economic relevance. Regional isolates of ACLSV and/or ASGV cause a severe phloem necrosis and decline of most commercial cultivars grafted on Maruba-kaido rootstock. ASPV is associated with several graft-transmissible disorders of economic relevance that cause damages to pear fruits, and ApMV usually induces symptoms of leaf mosaic (NICKEL \& FAJARDO, 2009).

Traditionally, viral infection assays in apple and pear have been based on the bioassay or ELISA serological technique. However, both techniques have distinct disadvantages associated with the space/time required, restriction to identify certain viral species (bioassays), absence of antibodies against important pathogens or inability to detect some viral agents (ELISA). In recent years, the incorporation of detection techniques based on molecular components of pathogens (conventional or real time RT-PCR) has significantly increased the detection limit but also the cost of the analysis. For this reason, trends in detection techniques have been focused on reducing the costs and time of the analysis by performing the simultaneous detection of several pathogens (DUBIELA et al., 2013). However, the cost resulting from these methods is incompatible with large-scale surveys, a very relevant aspect to be considered in the selection of diagnosis methods.

IEmbrapa Uva e Vinho, CP 130, 95700-000, Bento Gonçalves, RS, Brasil. E-mail: thor.fajardo@embrapa.br. *Autor para correspondência. Received 12.11.13 Approved 03.17.14 Returned by the author 07.12.14 CR-2013-1629.R1 
In this sense, the technology based on nonradioactive molecular hybridization is a fast, simple and reliable method for routine diagnosis of viruses. In recent years plant virus detection procedures have been devised to permit the simultaneous detection of the main pathogens affecting fruit cultures, in order to save time and reduce costs. Polyvalent detection by using the non-radioactive molecular hybridization technique has been performed in two different forms: first, by a mixture of the specific single probes in the hybridization solution, and secondly, by using a unique riboprobe, called polyprobe, that contains partial nucleic acid sequences of different viruses cloned in tandem (PEIRÓ et al., 2012). This method permits the simultaneous detection of different viruses in one test with detection limit similar to that obtained by ELISA. This technology has proved to be an efficient and cheap method for the detection of the main viruses affecting stone fruits (HERRANZ et al., 2005; PEIRÓ et al., 2012), tomatoes (APARICIO et al., 2009) and grapevines (FAJARDO et al., 2012). The objective of this study was to develop a polyprobe with the capacity to simultaneously detect four main viruses affecting apple and pear plants.

Samples came from apple and pear cultivars collected in commercial orchards of Southern Brazil and materials from our virus isolate collection. All apple and pear samples have been previously analyzed by conventional or real time RT-PCR and were known for most of their virus infections (NICKEL \& FAJARDO, 2009). Seedlings of apple plants used as healthy control and virus infected plants were subjected to total nucleic acids extraction by the silica capture method. Polyprobe was also hybridized with homologous viral cDNA individually cloned for each virus.

The assayed polyprobe contains a partial sequence of four virus species affecting apple and pear, ASGV, ACLSV, ASPV and ApMV. The complete coat protein gene of these four Brazilian viral isolates have been previously molecularly characterized: ASGV, UV01 isolate (NICKEL et al., 2001), ACLSV, BR1 isolate (SILVA et al., 2008), ASPV, br1 isolate (RADAELLI et al., 2006) and ApMV, M003 isolate (FAJARDO et al., 2011) in studies developed in the Virology Laboratory at Embrapa Grape \& Wine, Bento Gonçalves-RS, Brazil.

The construct contains the fusion of four pathogen sequences in 5'-3' order, ca. 400 nucleotides (nt) per each virus: ApMV, from nt 36 to 435, based on GenBank accession GQ131805; ACLSV, nt 66 to 466 (EF138602); ASGV, nt 42 to 441 (AF438409) and ASPV, nt 147 to 546 (AY572458). The incorporation of these four fragments into the pBluescript II SK plasmid and the subsequent fusion in tandem was performed by a commercial company generating a construct (pBSK-FAV) with $1601 \mathrm{bp}$ length and inserted with XbaI/SacI and SpeI/KpnI restriction sites in 5' and 3' orientation into the construct ends, respectively.

This recombinant clone, containing the FAV (four apple viruses) construct, was cultured for $8 \mathrm{~h}$ at $37^{\circ} \mathrm{C}$ in $\mathrm{LB}$ medium with $100 \mu \mathrm{g} \mathrm{mL}^{-1}$ ampicilin, and the plasmid DNA was purified using the Wizard Plus SV Minipreps DNA Purification System kit (Promega), according to the manufacturer's instructions. The FAV insert was removed from the cloning plasmid by digestion with XbaI/KpnI, and ligated to the pBluescript SK+ transcriptional vector, previously digested with the same enzymes. This clone was digested with $\mathrm{XbaI}$, aiming at its linearization for in vitro transcription. The 1601 bp FAV was transcribed in vitro with $\mathrm{T} 7$ RNA polymerase and transcribed RNA was simultaneously labeled with digoxigenin using DIG RNA Labeling kit (Roche), following the manufacturer's recommendations. After in vitro transcription, the synthesized probe was evaluated in agarose gels.

The synthesis of the digoxigenin labeled riboprobe and the hybridization reactions with the polyprobe were conducted as previously described (HERRANZ et al., 2005) with some modifications. For dot blot hybridization, total RNAs $(12.5 \mu \mathrm{L}$ total RNA at concentration of ca. 100ng total RNA $\mu \mathrm{L}^{-1}$ was dotted per sample) and homologous viral cDNA for each virus (ca. 125ng recombinant DNA plasmid was dotted per sample) were first denatured with formaldehyde and then applied onto positively charged nylon membranes (Sigma), using the BioDot apparatus (BioRad), air-dried and covalently fused by UV cross-linking $\left(700 \times 100 \mu \mathrm{J} \mathrm{cm} \mathrm{cm}^{-2}\right.$ for $3 \mathrm{~min}$ ).

The prehybridization was conducted at $68^{\circ} \mathrm{C}$ for $2 \mathrm{~h}$ in buffer solution containing $50 \%$ formamide, 5x SSC (20x SSC: $3 \mathrm{M} \mathrm{NaCl}, 0.3 \mathrm{M}$ sodium citrate, $\mathrm{pH} 7$ ), $0.1 \%$ N-lauroyl-sarcosine, $0.02 \%$ SDS, $2 \%$ blocking reagent (Roche). The hybridization was conducted at $60^{\circ} \mathrm{C}$ overnight in a hybridization oven using the polyprobe, previously denatured $\left(10 \mathrm{~min}\right.$ at $\left.65^{\circ} \mathrm{C}\right)$ and diluted $(1: 1000)$ in prehybridization solution. Thereafter, membranes were successively washed with $2 \mathrm{x}$ SSC containing $0.1 \% \operatorname{SDS}(2 \mathrm{x}$ for $5 \mathrm{~min}$ at room temperature), $0.1 \mathrm{x}$ SSC with $0.1 \% \operatorname{SDS}\left(2 \mathrm{x}\right.$ for $15 \mathrm{~min}$ at $60^{\circ} \mathrm{C}$ ) and maleic buffer $(0.1 \mathrm{M}$ maleic acid, $0.15 \mathrm{M} \mathrm{NaCl}, \mathrm{pH}$ 7.5 ) containing $0.3 \%$ Tween 20 ( $1 \mathrm{x}$ for $10 \mathrm{~min}$ at room 
temperature). Membranes were blocked for one hour at room temperature in maleic buffer containing $1 \%$ blocking reagent (Roche). Anti-digoxigenin antibody conjugated to alkaline phosphatase (Roche) was added to the blocking solution and incubated for one hour at room temperature. Two washes were performed with maleic buffer with $0.3 \%$ Tween 20 for $15 \mathrm{~min}$, and one wash with $0.1 \mathrm{M}$ Tris-HCl buffer $\mathrm{pH} 9.5,0.1 \mathrm{M}$ $\mathrm{NaCl}$ for $5 \mathrm{~min}$. The revelation was done by adding CDP-Star chemiluminescent substrate (Roche) onto the membrane and subsequent exposure to an X-ray film for 60min (HERRANZ et al., 2005; PEIRÓ et al., 2012).

The detection by polyprobe hybridization was accurate and consistent, and the spots (dark dots in the exposed film) were compatible with the presence of viruses in the samples and positive controls (Table 1). The signal intensity in the autoradiography was probably related to the viral titer in the analyzed samples considering that observed spots were specific reactions. No positive reactions were observed in assays of total RNA from apple healthy plants or 20x SSC buffer, demonstrating the specificity of this polyprobe.

The polyprobe carrying partial sequences of four apple viruses enabled the simultaneous detection of these pathogens using a non-radioactive molecular hybridization procedure. A comparative analysis of the used polyprobe and the previous conventional or real time RT-PCR results for detecting four apple and pear viruses is shown in table 1 . This is the first polyprobe described with the capacity of simultaneously detecting four different apple viruses.

In the present study, two aspects of the riboprobe technology were analyzed: first, the capacity to detect simultaneously four different viruses in the same assay (using total RNA), and secondly, whether the synthesized riboprobe is able to detect individual sequences of four viruses, contained in cDNA recombinant plasmids, relating these result with the specificity of the assay. For both aspects it was found

Table 1 - Comparative analysis of the use of polyprobe and the previous conventional or real time RT-PCR results for detecting four apple and pear viruses and polyprobe hybridization results with single and homologous virus, cloned in recombinant plasmids.

\begin{tabular}{|c|c|c|c|c|c|c|}
\hline \multirow{2}{*}{$\begin{array}{l}\text { Identification } \\
\text { number }\end{array}$} & \multirow{2}{*}{ Cultivar / sample description } & \multicolumn{4}{|c|}{----Previous conventional or real time RT-PCR results------ } & \multirow{2}{*}{$\begin{array}{l}\text { Hybridization } \\
\text { results }\end{array}$} \\
\hline & & ACLSV & ASGV & ASPV & ApMV & \\
\hline 42 & Williams - pear & + & + & - & - & + \\
\hline 48 & Abate Fetel - pear & - & + & + & - & + \\
\hline 195 & Maxi Gala - apple & - & + & + & + & + \\
\hline 257 & Maxi Gala - apple & - & + & + & + & + \\
\hline 258 & Maxi Gala - apple & + & + & + & - & + \\
\hline 260 & Maxi Gala - apple & - & + & + & - & + \\
\hline 266 & Maxi Gala - apple & - & + & + & - & + \\
\hline 269 & Maxi Gala - apple & + & + & + & - & + \\
\hline 270 & Maxi Gala - apple & - & + & + & - & + \\
\hline 339 & Fuji - apple & + & + & + & + & + \\
\hline 343 & Maxi Gala - apple & + & + & + & - & + \\
\hline 344 & Maxi Gala - apple & + & + & + & - & + \\
\hline 347 & Maxi Gala - apple & + & + & + & - & + \\
\hline 348 & Maxi Gala - apple & + & + & + & - & + \\
\hline 353 & Maxi Gala - apple & + & + & + & - & + \\
\hline 1097 & $\begin{array}{l}\text { Nicotiana occidentalis (tobacco, } \\
\text { experimental host) }\end{array}$ & + & - & - & - & + \\
\hline 1157 & Fuji Lee (Mishima) - apple & - & + & + & - & + \\
\hline 1160 & Braeburn - apple & + & + & + & + & + \\
\hline \multirow[t]{5}{*}{1168} & Royal Gala - apple & + & + & + & + & + \\
\hline & ACLSV cDNA clone & + & n.d. & n.d. & n.d. & + \\
\hline & ASGV cDNA clone & n.d. & + & n.d. & n.d. & + \\
\hline & ASPV cDNA clone & n.d. & n.d. & + & n.d. & + \\
\hline & ApMV cDNA clone & n.d. & n.d. & n.d. & + & + \\
\hline
\end{tabular}

n.d. not determined, + infected or positive sample, - healthy or negative sample.

Ciência Rural, v.44, n.10, out, 2014. 
that the evaluated riboprobe did not compromise the virus detection of assayed samples (Table 1).

Supporting the relevance of the present results for pathogen detection using molecular probes, in many studies, molecular non-radioactive hybridization for simultaneous detection of different viruses and/or viroids using a single probe or polyprobe containing different viral and/or viroidal nucleotide sequences has been developed, and successfully used for pathogen diagnosis (HERRANZ et al., 2005; APARICIO et al., 2009; FAJARDO et al., 2012; PEIRÓ et al., 2012).

Polymerase chain reaction (PCR) and hybridization are generally used for diagnosis. The PCR is a detection method with high sensitivity. However it has the disadvantage of producing falsepositives, due to contamination, or false-negatives caused by inhibitors or because of the high primer specificity. The use of nucleic acid hybridization with non-radiolabeled probes is a good diagnostic alternative for bringing together practicality and sensibility in the same test, with no special equipment requirement and easy handling.

Viruses associated with apple and pear diseases are frequently found in mixed infections. As a consequence polyprobe hibridization could be useful for testing mother plants in certification programs for production of healthy apple and pear materials. In summary, the use of the polyprobe described above could be a useful and reliable alternative as a first step to determine the phytosanitary status of plants in routine diagnosis or a complementary doublechecking detection method. The method described saves time and cost and allows simultaneous detection of four viruses in large numbers of samples in a single reaction.

\section{ACKNOWLEDGMENTS}

To Francisco J.L. Aragão (Embrapa Recursos Genéticos e Biotecnologia) for supporting the customized synthesis of the first construct used in this study.

\section{REFERENCES}

APARICIO, F. et al. Simultaneous detection of six RNA plant viruses affecting tomato crops using a single digoxigenin-labelled polyprobe. European Journal of Plant Pathology, v.123, p.117-123, 2009. Available from: <http://download.springer.com/static/pdf/314/art\% 253A10.1007\%252Fs10658-008-9347-5.pdf?auth66=1399548828_ b9c050748ea46c1d2f3ee60bb6056d21\&ext=.pdf>. Accessed: Feb. 18, 2014. doi: 10.1007/s10658-008-9347-5.

DUBIELA, C.R. et al. Simultaneous detection of Brazilian isolates of grapevine viruses by TaqMan real-time RT-PCR. Tropical Plant Pathology, v.38, p.158-165, 2013. Available from: <http:// www.scielo.br/pdf/tpp/v38n2/a11v38n2.pdf>. Accessed: Feb. 18, 2014. doi: 10.1590/S1982-56762013000200011.

FAJARDO, T.V.M. et al. Detecção e caracterização molecular dos genes da proteína capsidial de ilarvírus e ampelovírus que infectam fruteiras temperadas. Ciência Rural, v.41, p.5-9, 2011. Available from: <http://www.scielo.br/pdf/cr/v41n1/ a816cr4149.pdf>. Accessed: Feb. 18, 2014. doi: 10.1590/S010384782011000100002 .

FAJARDO, T.V.M. et al. Detecção simultânea de vírus em videira por hibridização com polissonda. In: CONGRESSO BRASILEIRO DE FRUTICULTURA, 22., 2012, Bento Gonçalves, RS. Anais... Bento Gonçalves: SBF, 2012. p.2191-2195.

HERRANZ, M.C. et al. Simultaneous detection of six stone fruit viruses by non-isotopic molecular hybridization using a unique riboprobe or polyprobe. Journal of Virological Methods, v.124, p.49-55, 2005. Available from: <http://ac.els-cdn.com/ S0166093404003362/1-s2.0-S0166093404003362-main.pdf?_ tid=e3f10c8c-98b9-11e3-b46f-00000aacb35d\&acdnat $=1392741$ 171_95aa2b8ddb9e2bf19a1d0cc8ef0c7b93>. Accessed: Feb. 18, 2014. doi: 10.1016/j.jviromet.2004.11.003

NICKEL, O. et al. Sequence analysis of the capsid protein gene of an isolate of Apple stem grooving virus, and its survey in Southern Brazil. Fitopatologia Brasileira, v.26, p.655-659, 2001. Available from: <http://www.scielo.br/pdf/fb/v26n3/a14v26n3.pdf>. Accessed: Feb 18, 2014. doi: 10.1590/S0100-41582001000300014.

NICKEL, O.; FAJARDO, T.V.M. Obtenção de material propagativo livre de vírus e diagnóstico de vírus em macieiras e pereiras. Bento Gonçalves: Embrapa Uva e Vinho, 2009. 55p. (Documentos, 69).

PEIRÓ, A. et al. Simultaneous detection of eight viruses and two viroids affecting stone fruit trees by using a unique polyprobe. European Journal of Plant Pathology, v.132, p.469-475, 2012. Available from: <http://download.springer.com/static/pdf/939/art \%253A10.1007\%252Fs10658-011-9893-0.pdf?auth66=13995490 93_3ce037870c857bf70e7f9135dca093b2\&ext=.pdf $>$. Accessed: Feb. 18, 2014. doi: 10.1007/s10658-011-9893-0.

RADAELLI, P. et al. Diagnóstico biológico e molecular e análise da sequência de nucleotídeos do gene da proteína capsidial de um isolado do Apple stem pitting virus. Fitopatologia Brasileira, v.31, p.51-56, 2006. Available from: <http://www.scielo.br/pdf/ fb/v31n1/a09v31n1.pdf>. Accessed: Feb. 18, 2014. doi: 10.1590/ S0100-41582006000100009.

SILVA, F.N. et al. Indexação biológica múltipla e RT-PCR para detecção de vírus latentes em macieiras. Tropical Plant Pathology, v.33, p.157-161, 2008. Available from: <http://www. scielo.br/pdf/tpp/v33n2/a11v33n2.pdf>. Accessed: Feb. 18, 2014. doi: 10.1590/S1982-56762008000200011. 